\title{
Pituitary adenylate cyclase activating polypeptide and nitric oxide synthase are expressed in the rat ciliary ganglion
}

\author{
Tor Elsås, Rolf Uddman, Hindrik Mulder, Frank Sundler
}

Department of

Ophthalmology,

Trondheim, Norway

T Elsås

Department of Oto-Rhino-Laryngology, Malmö General Hospital, Malmö, Sweden

R Uddman

Department of Physiology and Neuroscience, Section for Neuroendocrine Cell Biology, University of Lund, Sweden

H Mulder

F Sundler

Correspondence to: Tor Elsås, Department of Ophthalmology, University Hospital of Trondheim, N-7006, Trondheim Norway.

Accepted for publication 25 November 1996

\begin{abstract}
Aims-To study the distribution in the rat ciliary ganglion of neurons synthesising and storing the recently discovered neuropeptide pituitary adenylate cyclase activating polypeptide (PACAP) and neuronal nitric oxide synthase (NOS), the neuronal marker of the novel gaseous transmitter nitric oxide.

Methods-Neurons expressing PACAP and neuronal NOS mRNA were identified in the rat ciliary ganglion by in situ hybridisation with radiolabelled oligonucleotide probes. Immunocytochemistry was used to demonstrate immunoreactive neuropeptides and NOS.

Results-Immunocytochemistry demonstrated immunoreactivity for PACAP and NOS in a small number of neuronal cell bodies. In situ hybridisation revealed that NOS and PACAP were expressed in numerous ganglion cell somata. The well established ciliary messengers vasoactive intestinal peptide and neuropeptide $Y$ were found in a large number of neuronal cell bodies.

Conclusion-These results demonstrate that PACAP and NOS are synthesised and stored in the ciliary ganglion. These findings further illustrate the mixed nature of the ciliary ganglion and may provide a basis for the understanding of the diverse physiological functions of this ganglion. (Br F Ophthalmol 1997;81:223-227)
\end{abstract}

The concept of the ciliary ganglion as a purely cholinergic, parasympathetic ganglion has been challenged by the finding of not only parasympathetic but also sympathetic and sensory transmitters in this ganglion. ${ }^{1-4}$ Recently, a host of novel neuronal messengers that override the 'classic' taxonomy of sympathetic, parasympathetic, and sensory messengers has been identified. For instance, pituitary adenylate cyclase activating polypeptide (PACAP) is a vasoactive intestinal peptide (VIP)-like neuropeptide, initially isolated from ovine hypothalamus, which is expressed both in the sensory and autonomic nervous system. ${ }^{5-8}$ Fur- ther, the identification of nitric oxide (NO) as a neuronal and non-neuronal messenger is of particular interest owing to its chemical identity, its wide distribution, and its broad spectrum of effects. ${ }^{9}$ Because of its high lability, information on the cellular localisation and the site of formation of $\mathrm{NO}$ has been attained by immunocytochemistry and in situ hybridisation for nitric oxide synthase (NOS), ${ }^{10}{ }^{11}$ or by the histochemical technique for demonstration of NADPH diaphorase, which stains neurons containing NOS. ${ }^{11-13}$

VIP and neuropeptide Y (NPY) are well established as neuropeptides in the ciliary ganglion and the eye, and seem to exert several physiological effects on ocular structures. ${ }^{2-414} 15$

Given the wide range of suggested physiological roles for the ciliary ganglion, we have in the present study used in situ hybridisation and immunocytochemistry to investigate whether rat ciliary neurons express these novel messengers - that is, PACAP and NOS, and compared this with the expression of the established ciliary messengers NPY and VIP.

\section{Materials and methods}

Twelve adult female Sprague-Dawley rats (body weight 200-250 g) were used. The animals were anaesthetised by chloralose and killed by exsanguination, the ciliary ganglion was subsequently dissected. For in situ hybridisation, the specimens were rapidly frozen on dry ice and stored at $-80^{\circ} \mathrm{C}$ until they were cut on a cryostat $(10 \mu \mathrm{m})$. For immunocytochemistry, the specimens were fixed by immersion in a mixture of $2 \%$ formaldehyde and $0.2 \%$ picric acid solution in $0.1 \mathrm{M}$ phosphate buffer $(\mathrm{pH}$ 7.2) overnight, followed by repeated rinsing in a Tyrode solution containing $10 \%$ sucrose. They were then frozen on dry ice and stored at $-80^{\circ} \mathrm{C}$. The specimens were sectioned at 10 $\mu \mathrm{m}$ thickness in a cryostat.

\section{IN SITU HYBRIDISATION}

The cellular localisation of mRNAs for PACAP, NOS, VIP, NPY, and calcitonin gene related peptide (CGRP) in the rat ciliary ganglion was determined by in situ hybridisation, using oligodeoxyribonucleotide probes. These probes have previously been charac- 
Table 1 Details of the antisera used for immunocytochemistry

\begin{tabular}{|c|c|c|c|c|c|}
\hline Antigen & Code & Raised against & Raised in & $\begin{array}{l}\text { Working } \\
\text { dilution }\end{array}$ & Source \\
\hline PACAP-27 & $88121-3$ & Protein conjugated synthetic PACAP-27 & Rabbit & $1: 640$ & Dr A Arimura, Lousiana, USA \\
\hline NOS & 9223 & $\begin{array}{l}\text { Synthetic fragment of rat cerebellar } \\
\text { NOS }\end{array}$ & Rabbit & $1: 2560$ & Euro-Diagnostica, Malmö, Sweden \\
\hline VIP & 7852 & Unconjugated pure porcine VIP & Rabbit & $1: 640$ & Euro-Diagnostica, Malmö, Sweden \\
\hline NPY & E2210 & Protein conjugated porcine NPY & Sheep & $1: 800$ & $\begin{array}{l}\text { Dr J Furness, Flinders University, } \\
\text { Bedford Park, Australia }\end{array}$ \\
\hline CGRP & 8427 & Protein conjugated rat CGRP & Rabbit & $1: 640$ & Euro-Diagnostica, Malmö, Sweden \\
\hline
\end{tabular}

terised. $^{781617}$ To ensure that the probes displayed no sequence homology to other known mRNAs, a computerised database search was performed; no such homologies were discovered (Genbank EMBL 3/96). The probes were 3 '-endtailed by terminal transferase to a specific activity of approximately $2 \times$ $10^{9} \mathrm{cpm} / \mu \mathrm{g}$ as described previously. ${ }^{7}$

The hybridisation protocol used has been described in detail elsewhere. ${ }^{7}$ Briefly, the fresh frozen sections were rapidly warmed to room temperature and fixed in $4 \%$ paraformaldehyde. The sections were acetylated by $0.25 \%$ acetic anhydride in $0.1 \mathrm{M}$ triethanolamine, dehydrated, and cleared in chloroform. Hybridisation was carried out overnight in sealed moist chambers at $37^{\circ} \mathrm{C}$ using probe concentrations of approximately $1 \mathrm{pmol} / \mathrm{ml}$. After hybridisation, the sections were washed in $1 \times$ SSC $(1 \times$ SSC $=0.15 \mathrm{M} \mathrm{NaCl}, 0.015 \mathrm{M}$ sodium citrate; $4 \times 15$ minutes, $55^{\circ} \mathrm{C}+1 \times 30$ minutes, room temperature). The slides were dipped in Ilford $\mathrm{K} 5$ emulsion and exposed for 2 to 3 weeks.

For control purposes, sections were incubated in RNase A ( $45 \mu \mathrm{g} / \mathrm{ml}$; Sigma, St Louis, $\mathrm{MO}$, USA) for 30 minutes at $37^{\circ} \mathrm{C}$ before hybridisation. As an additional control a 100-fold molar excess of unlabelled probe was added to the hybridisation buffer.

IMMUNOCYTOCHEMISTRY

For the immunocytochemical demonstration of PACAP, NOS, VIP, NPY, and CGRP indirect immunofluorescence was used. Details of the primary antibodies are given in Table 1 . The sections were exposed to the primary antiserum overnight at $4^{\circ} \mathrm{C}$ in a moist chamber. The site of the antigen-antibody reaction was revealed by application of fluorescein isothiocyanate (FITC) labelled antibodies raised against rabbit immunoglobulin $\mathrm{G}$ (Dakopatts, Copenhagen, Denmark), in a dilution of 1:320 for 1 hour at room temperature. Control sections were exposed to antiserum that had been preabsorbed with an excess amount of the antigen (10-100 $\mu \mathrm{g}$ of synthetic peptide per $\mathrm{ml}$ diluted antiserum). Additionally, the antiserum was tested for cross reaction with other peptides (10-100 $\mu \mathrm{g}$ of peptide per ml diluted antiserum). No such cross reaction was found.

Cross reactions with still other peptides or proteins containing amino acid sequences recognised by the different antisera cannot be excluded. It is appropriate, therefore, to refer to the immunoreactive material as NOS-like, VIP-like, and so on. For brevity, however, the shorter terms NOS and VIP will be used henceforth.

\section{Results}

IN SITU HYBRIDISATION

Almost all neuronal cell bodies displayed some labelling with an intensity that varied from weak to strong. When labelled cells were counted in random sections from the rat ciliary ganglion, approximately $20 \%$ of the ganglion cell somata demonstrated strong labelling for PACAP and NOS mRNA as evidenced by a high density of autoradiographic grains (Fig 1A, B). The corresponding figures for the VIP and NPY probes were 35\% (Fig 1C, D). The intensity of labelling varied between the cells, but was consistently weaker for PACAP mRNA. The NOS and NPY probes showed strong and uniform labelling, while the probes for PACAP and VIP mRNA demonstrated variability in the intensity of labelling of the neuronal cell bodies. Cell bodies harbouring CGRP mRNA were not observed.

When the sections were treated with RNase A before hybridisation or when an excess of unlabelled probe was added to the hybridisation buffer, autoradiographic labelling of nerve cell bodies was abolished. Usually the sections demonstrated probe labelling, but occasional sections were negative.

\section{IMMUNOCYTOCHEMISTRY}

Scattered nerve cell bodies harboured immunoreactivity for PACAP (Fig 2A) or NOS (Fig $2 \mathrm{~B}$ ), which also occurred in varicose nerve fibres within the ganglion. When neuronal cell bodies immunoreactive for PACAP and NOS were counted in random sections of the rat ciliary ganglion, scattered perikarya contained PACAP or NOS. A rich supply of nerve cell bodies, about $30 \%$, contained VIP or NPY (Fig 2C, D). Immunoreactivity for CGRP was not observed in ciliary ganglion cells.

The sections exposed to antibodies against VIP or NPY usually showed some degree of labelling of ganglion cell somata. Several of the slides treated with antibodies against PACAP or NOS were negative, probably due to the low number of cells harbouring immunoreactivity for PACAP or NOS.

\section{Discussion}

The classic concept of the ciliary ganglion as being a pure parasympathetic ganglion has been replaced by the view of it being a mixed ganglion comprised of neurons exhibiting parasympathetic, sympathetic, and sensory neuromessenger phenotypes. Although ciliary 

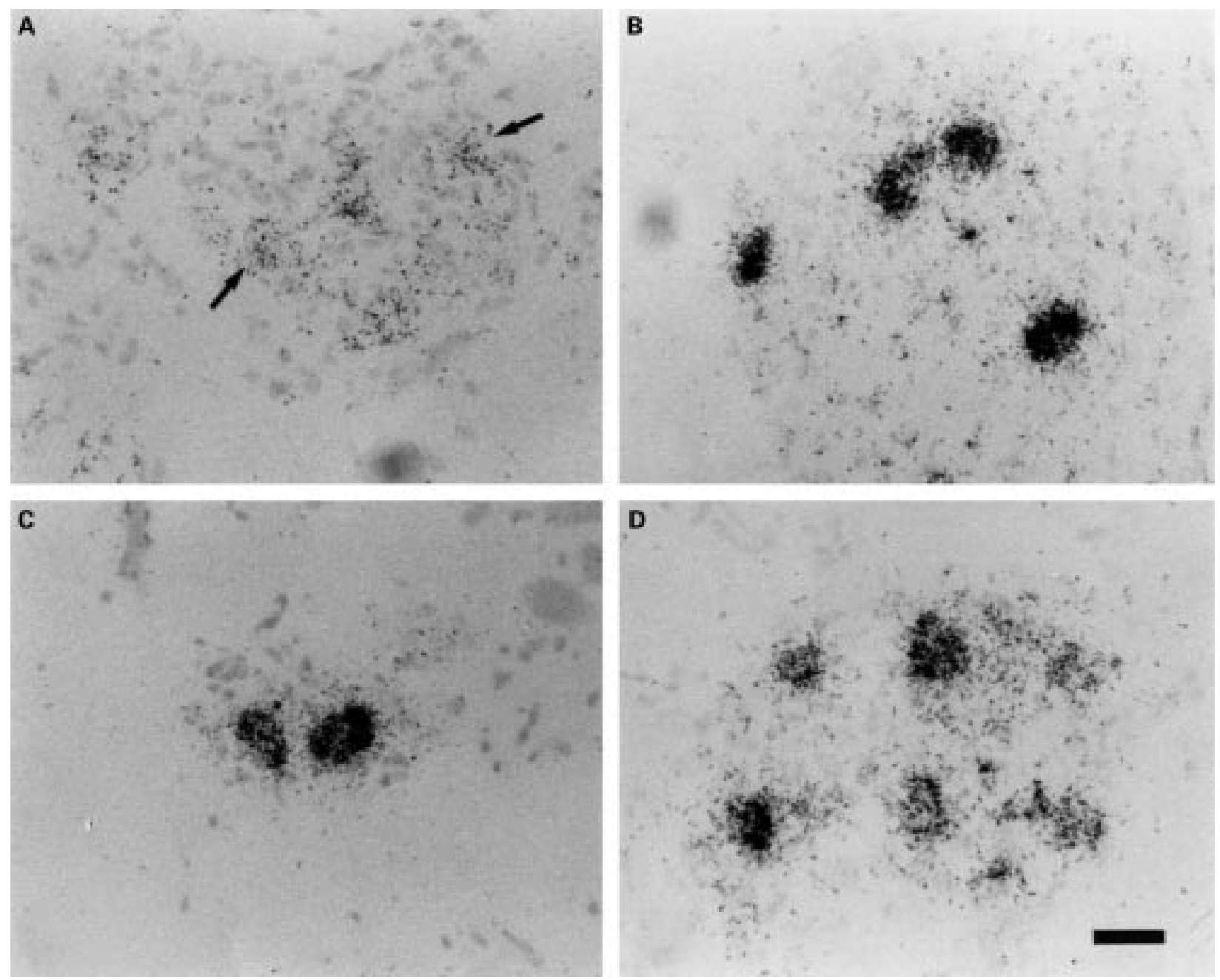

Figure 1 In situ hybridisation with radiolabelled oligonucleotide probes for PACAP $m R N A(A), N O S m R N A(B), V I P m R N A(C)$, and NPY $m R N A$ (D) in the ciliary ganglion of the rat. A moderate number of nerve cell bodies expressing PACAP, albeit at a low level is seen ( $A$; indicated by arrows). NOS $m R N A$ is present in a moderate number of nerve cell bodies $(B)$, while VIP and NPY are seen in greater number of nerve cell bodies $(C, D) ;$; in this particular section labelled for VIP $m R N A$, all nerve bodies express VIP $(C)$. Bar $=50 \mu m$.

cell bodies exhibit immunoreactivity for choline acetyltransferase, immunocytochemical studies have revealed that the rat ciliary ganglion, in addition, harbours nerve cell bodies containing VIP, NPY, CGRP, and leu-enkephalin. ${ }^{1-4}{ }^{18}$ It also contains nerve cell bodies immunoreactive for tyrosine hydroxylase and dopamine $\beta$ hydroxylase. ${ }^{19}$

Our study demonstrates that PACAP is also expressed in the rat ciliary ganglion; a sparse supply of nerve cell bodies in the ciliary ganglion harboured immunoreactivity for PACAP, while around $20 \%$ of the ciliary neuronal cell bodies demonstrated strong labelling for PACAP mRNA. PACAP is a recently discovered neuropeptide with a marked sequence homology with VIP. ${ }^{5}$ Nerve cell bodies containing PACAP mRNA and PACAP immunoreactivity can be seen in the sphenopalatine and otic ganglia, where PACAP colocalises with VIP. ${ }^{8}$ Our demonstration of PACAP expression in ciliary neurons is of particular interest in relation to findings demonstrating the presence of PACAP receptors in ocular tissues of the rabbit, and further, that in the rabbit choroid PACAP is about 100 times more potent than VIP as a vasodilator. ${ }^{20}{ }^{21} \mathrm{Sev}-$ eral lines of evidence suggest that PACAP in addition to its autonomic functions also acts as a sensory neuropeptide, since nerve cell bodies in sensory ganglia contain PACAP-like immunoreactivity and PACAP mRNA. ${ }^{6}$ Furthermore, PACAP depresses a nociceptive spinal reflex. ${ }^{22}$ Wang et al ${ }^{23}$ found a CGRP-like distribution of PACAP in the rabbit eye, and that PACAP probably mediated inflammatory effects.

Around $20 \%$ of the perikarya in the ciliary ganglion revealed strong labelling for NOS mRNA, while only scattered ganglion cell somata were immunoreactive for NOS. These results and previous findings of NOS immunoreactive and NADPH diaphorase stained ciliary neurons makes it highly likely that ciliary neurons employ $\mathrm{NO}$ as a neuronal messenger. ${ }^{1124}$ Recently, several functional studies have indicated that NO is an important mediator of inhibitory non-adrenergic, noncholinergic responses. For instance, there is evidence that neuronal NO, released upon electrical stimulation, takes part in nonadrenergic, non-cholinergic relaxation of smooth muscle in the bronchi and the digestive tract. ${ }^{25-27}$ Moreover, several studies suggest that 

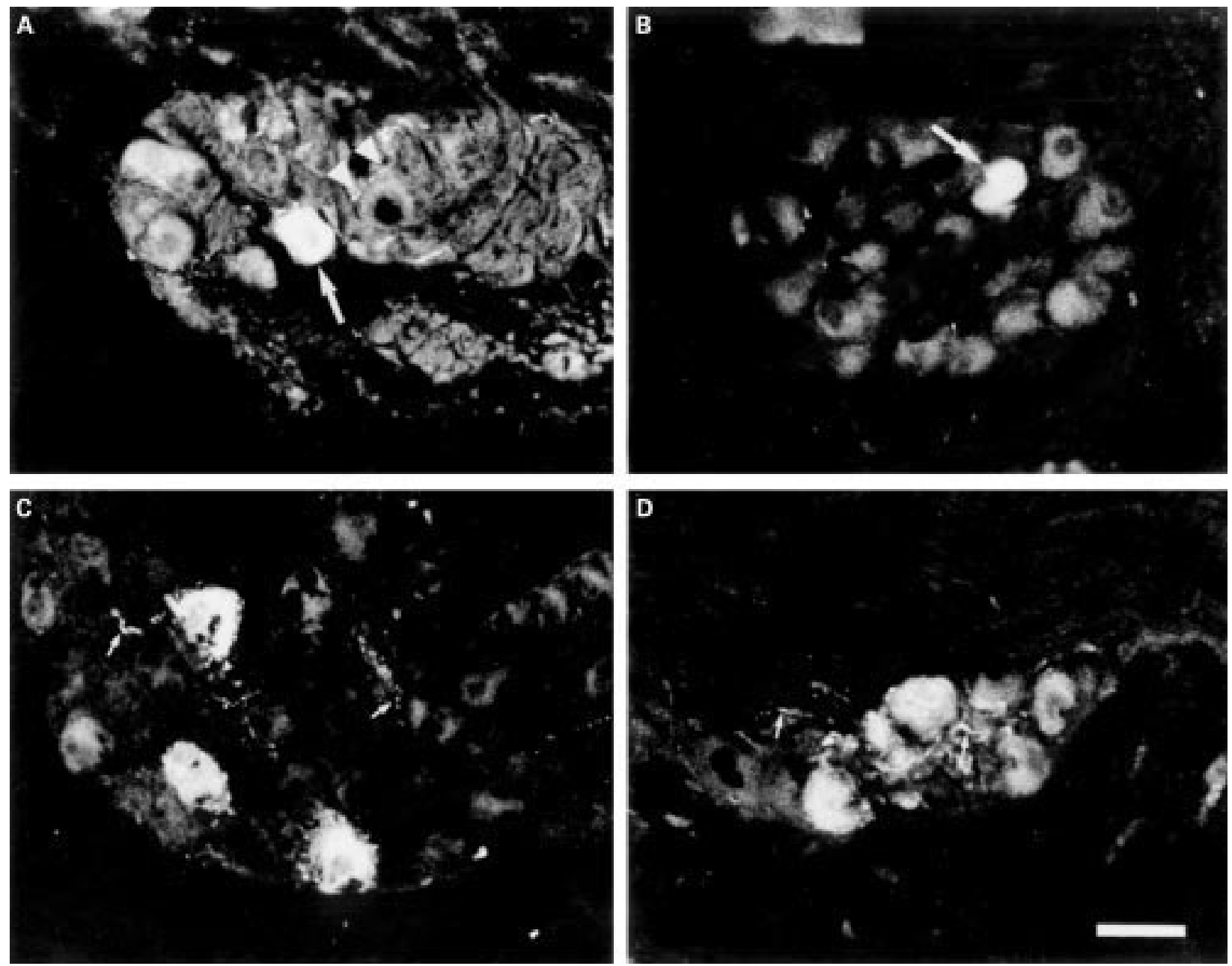

Figure 2 Immunofluorescence for PACAP $(A), N O S(B), V I P(C)$, and NPY $(D)$ in the ciliary ganglion of the rat. A solitary PACAP immunoreactive nerve cell body ( $A$; arrow) is seen as well as a supply of fine varicose PACAP-containing nerve fibres ( $A$; indicated by arrowheads). NOS is harboured in a moderate number of nerve cell bodies (B; indicated by a solitary nerve cell body, arrow), while VIP and NPY occur in numerous nerve cell bodies and fibres in the ciliary ganglion ( $C, D$; fibres indicated by arrows). Bar $=50 \mu \mathrm{m}$.

NO plays an important role in the regulation of ocular blood vessels. ${ }^{28-32}$

There are conflicting data regarding the number of ciliary ganglion cells containing VIP. Suzuki et $\mathrm{al}^{3}$ reported the presence of VIP in almost all ciliary cell bodies, while Leblanc et $a l^{1}$ and Stone et $a l^{2}$ only found VIP in a minority of the ciliary ganglion cells. The demonstration of VIP both by in situ hybridisation and immunocytochemistry in numerous ciliary ganglion cells in the present study supports the view that VIP is an important neuropeptide in the ciliary ganglion.

A rich supply of neuronal ciliary cell bodies expressed NPY. This is in concert with findings in other studies. ${ }^{24}$ Tyrrell et $a l^{4}$ found that $85 \%$ of the rat ciliary ganglion cells contained NPY mRNA. In sympathetic ganglia, such as the superior cervical ganglion, NPY-containing nerve cell bodies are numerous. In addition, a moderate supply of NPY-containing cell bodies can be seen in parasympathetic ganglia such as the otic and sphenopalatine ganglia. ${ }^{33}$ The NPY fibres repopulating the iris following long term sympathectomy arise from the ciliary ganglion. ${ }^{34}$ The ciliary ganglion as well as the sphenopalatine ganglion could well be a source for the NP-containing nerve fibres remaining in the choroid following removal of the superior cervical ganglion.

One interesting aspect of the present study is the much higher sensitivity of the mRNA probes in labelling neuropeptide-containing neuronal cell bodies compared with immunocytochemistry. Similar findings were reported by Tyrrell et al. ${ }^{4}$ In the rat ciliary ganglion, 25\% of the neuronal cell bodies were NPY immunoreactive and $85 \%$ expressed NPY mRNA. Studies on the distribution of PACAP and NOS in cranial ganglia show corresponding findings with a much higher detection rate with in situ hybridisation compared with immunocytochemistry. ${ }^{816}$ The discrepancy between the sensitivity of immunocytochemistry and in situ hybridisation raises the possibility that neuropeptides are present in many ciliary neuronal cell bodies at levels not detectable with immunocytochemistry.

We were unable to find CGRP-containing nerve cell bodies in the present study using either in situ hybridisation or immunocytochemistry. However, Stone et $a l^{2}$ reported CGRP immunoreactivity in around $25 \%$ of the neuronal cell bodies in the rat ciliary ganglion.

In conclusion, the present study demonstrates expression of the novel neuromessen- 
gers PACAP and NOS, as well as VIP and NPY in the rat ciliary ganglion. This further highlights the complexity of the ganglion, suggesting its participation in multiple physiological functions.

This study was supported by the Swedish Medical Research Council (project no 12X-4499), The Albert Påhlsson and Crafoord Foundations, the Faculty of Medicine, Lund University, Nycomed's grant for Norwegian ophthalmologists, Nordic Research Council, Norwegian Medical Research Council, and the Ophthalmological Society of Central Norway.

1 Leblanc GL, Trimmer BA, Landis SC. Neuropeptide Y-like immunoreactivity in rat cranial parasympathetic neurons: coexistence with vasoactive intestinal peptide and choline acetyltransferase. Proc Natl Acad Sci USA 1987;84:3511-5.
Stone RA, McGlinn AM, Kuwayama Y, Grimes PA. Peptide Stone RA, McGlinn AM, Kuwayama Y, Grimes PA. Peptide
immunoreactivity of the ciliary ganglion and its accessory immunoreactivity of the ciliary ganglion and

3 Suzuki N, Hardebo JE, Kåhrstrøm J, Owman C. Neuropeptide $\mathrm{Y}$ co-exists with vasoactive intestinal polypeptide and acetylcholine in parasympathetic cerebrovascular nerves originating in the sphenopalatine, otic, and internal carotid ganglia of the rat. Neuroscience 1990;36:507-19.

4 Tyrrell S, Siegel RE, Landis SC. Tyrosine hydroxylase and neuropeptide $\mathrm{Y}$ are increased in ciliary ganglia of sympathectomized rats. Neuroscience 1992;47:985-98.

5 Miyata A, Arimura A, Dahl RD, Minamino N, Uehara A, Jiang L, et al. Isolation of a novel 38 residue-hypothalamic polypeptide which stimulates adenylate cyclase in pituitary cells. Biochem Biophys Res Commun 1989;164:567-74.

6 Moller K, Zhang YZ, Håkanson R, Luts A, Sjölund B, Uddman $\mathrm{R}$, et al. Pituitary adenylate cyclase activating peptide is a sensory neuropeptide: Immunocytochemical and immunochemical evidence. Neuroscience 1993;57:725and im

7 Mulder H, Uddman R, Moller K, Zhang YZ, Ekblad E, Alumets J, et al. Pituitary adenylate cyclase activating polypeptide expression in sensory neurons. Neuroscience 1994;63:307-12.

8 Mulder $\mathrm{H}$, Uddman R, Moller $\mathrm{K}$, Elsås T, Ekblad $\mathrm{E}$, Alumets J, et al Pituitary adenylate cyclase activating polypeptide is expressed in autonomic neurons. Regul Pept 1995;59:121-8

9 Moncada S, Palmer RMJ, Higgs EA. Nitric oxide: physiology, pathophysiology, and pharmacology. Pharmacol Rev 1991;43:109-42.

10 Bredt DS, Hwang PM, Glatt C, Lowenstein C, Snyder SH Cloned and expressed nitric oxide synthase structurally resembles cytochrome P-450 reductase. Nature 1991:351: 714-8.

11 Yamamoto R, Bredt DS, Snyder SH, Stone RA. The localization of nitric oxide synthase in the rat eye and related zation of nitric oxide synthase in the rat eye

12 Dawson TM, Bredt DS, Fotuhi M, Hwang PM, Snyder SH. Nitric oxide synthase and neuronal NADPH diaphorase Nitric oxide synthase and neuronal NADPH diaphorase are identical in brain and periph

13 Hope BT, Michael GJ, Knigge KM, Vincent SR. Neuronal NADPH diaphorase is a nitric oxide synthase. Proc Nat Acad Sci USA 1991;88:2811-4

14 Nilsson SFE, Bill A. Vasoactive intestinal polypeptide (VIP): effects in the eye and on regional blood flows. Acta Physio Scand 1984;121:385-92

15 Nilsson SFE. Neuropeptide Y (NPY): a vasoconstrictor in the eye, brain and other tissues in the rabbit. Acta Physiol Scand 1991;141:455-67.

16 Uddman R, Mulder H, Sundelin J, Elsås T, Sundler F. Nitric oxide synthase expression in cervical autonomic and sensory ganglia in rat: relationship to neuropeptides. Cell Vision 1994; 1:306-12.

17 Myrsen U, Sundler F. Neuropeptide Y is expressed in islet somatostatin cells of the hamster pancreas: a combined immunocytochemical and in situ hybridization study. Regul Pept 1995;57:65-76.

18 Kuwayama Y, Grimes PA, Ponte B, Stone RA. Autonomic neurons supplying the rat eye and the intraorbital distribution of vasoactive intestinal polypeptide (VIP)-like bution of vasoactive intestinal polypeptide
immunoreactivity. Exp Eye Res 1987;44:907-22.

19 Landis SC, Jackson PC, Fredieu JR, Thibault J. Catecholaminergic properties of cholinergic neurons and synapses in adult rat ciliary ganglion. $\mathcal{F}$ Neurosci $1987 ; 7: 3574-87$.

20 Nilsson SFE, De Neef P, Robberecht P, Christophe J. Characterization of ocular receptors for pituitary adenylate cyclase activating polypeptide (PACAP) and their coupling to adenylate cyclase. Exp Eye Res 1994;58:459-67.

21 Nilsson SFE. PACAP-27 and PACAP -38; vascular effects in the eye and some other tissues in the rabbit. Eur f Pharmacol 1994;253:17-25.

22 Zhang YZ, Sjölund B, Moller K, Håkanson R, Sundler F. Pituitary adenylate cyclase activating peptide produces a marked and long-lasting depression of a C-fibre-evoked flexion reflex. Neuroscience 1993;57:733-7.

23 Wang ZY, Alm P, Håkanson R. Distribution and effects of pituitary adenylate cyclase-activating peptide in the rabbit eye. Neuroscience 1995;69:297-308.

24 Sun W, Erichsen JT, May PJ. NADPH-diaphorase reactivity in ciliary ganglion neurons: a comparison of distributions in the pigeon, cat, and monkey. Vis Neurosci 1994;11:1027-

25 Tucker JF, Brave SR, Charalambous L, Hobbs AJ, Gibson A. L-N ${ }^{\mathrm{G}}$-nitro arginine inhibits non-adrenergic, noncholinergic relaxations of guinea pig isolated tracheal smooth muscle. Br 7 Pharmacol 1990;100:663-4.

$26 \mathrm{Li} \mathrm{CG}$, Rand MJ. Evidence that part of the NANC relaxant response of the guinea-pig trachea to electric field stimulation is mediated by nitric oxide. Br f Pharmacol 1991;102: 91-4

27 Tøttrup A, Knudsen MA, Gregersen $H$. The role of L-arginine-nitric oxide pathway in relaxation of the opossum lower oesophageal sphincter. $\mathrm{Br} F$ Pharmacol 1991;104:113-6.

28 Haefliger IO, Flammer J, Lüscher TF. Nitric oxide and endothelin-1 are important regulators of human ophthal endothelin-1 are important regulators of human oph
mic artery. Invest Ophthalmol Vis Sci 1992;33:2340-3.

29 Haefliger IO, Flammer J, Lüscher TF. Heterogeneity of endothelium-dependent regulation in ophthalmic and ciliary arteries. Invest Ophthalmol Vis Sci 1993;34:1722-30.

30 Wiencke AK, Nilsson H, Nielsen PJ, Nyborg NCB. Nonadrenergic noncholinergic vasodilation in bovine ciliary artery involves CGRP and neurogenic nitric oxide. Invest Ophthalmol Vis Sci 1994;35:3268-77.

31 Mann RM, Riva CE, Stone RA, Barnes GE, Cranstoun SD. Nitric oxide and choroidal blood flow regulation. Invest Ophthalmol Vis Sci 1995;36:925-30.

32 Toda N, Kitamura Y, Okumara T. Functional role of nervederived nitric oxide in isolated dog ophthalmic arteries. Invest Ophthalmol Vis Sci 1995;36:563-70.

33 Leblanc GL, Landis SC. Target specificity of neuropeptide Y-immunoreactive cranial parasympathetic neurons. 7 Neurosci 1988;8:146-55.

34 Björklund H, Hökfelt T, Goldstein M, Terenius L, Olson L. Appearance of the noradrenergic markers tyrosine hydroxylase and neuropeptide $\mathrm{Y}$ in cholinergic nerves of the iris following sympathectomy. F Neurosci 1985;5:163343.

35 Terenghi G, Polak JM, Allen JM, Zhang SQ, Unger WG, Bloom SR. Neuropeptide Y-immunoreactive nerves in the uvea of guinea pig and rat. Neurosci Lett 1983;42:33-8. 